Revista Iberoamericana, Vol. LXXV, Núm. 226, Enero-Marzo 2009, 33-53

\title{
VIRGILIO PIÑERA, CONTRA Y POR LA PALABRA
}

\author{
POR \\ RITA MaRTin \\ Davidson College
}

Al recoger y publicar bajo el título La vida entera (1968) los poemas que escribiese entre 1941 y 1968, Virgilio Piñera (1912-1979) afirma, en una breve nota de presentación a la colección, haberse considerado siempre "un poeta ocasional". Añade que el único motivo de la edición de sus "poesías" es dejar "[su] casa en orden antes de cerrar, por última vez, sus puertas" (19). Para el escritor y crítico Antón Arrufat (1935), esta "displicencia” ante la poesía "pudo ser el resultado de varios factores externos", entre los que anota la pobreza, la imposibilidad de Virgilio como él sencillamente se hacía llamar, de pagarse sus propias ediciones, y la actitud de éste, factores que, al decir que, al decir del crítico, "lo llevaron a enajenarse de uno de los centros actuantes de su momento: primero del grupo de Espuela de Plata, después del de Orígenes” (“Notas prologales” 10).

El testimonio de Arrufat sobre el poeta que fuera Virgilio Piñera informa también sobre la actitud de aquel ante la poesía. Además del reclamo piñeriano de que el poeta estableciera una obra cerrada o concentrada, Virgilio, según Arrufat, conservaba, por un lado, una “elevada valoración de la poesía y del poeta”, mientras que, por el otro lado, "su escritura estuvo signada por cierto desencanto del valor de la literatura, que lo llevaba a descreer de la poesía y del poeta: posición crítica frente al artificio y las falsedades a los que conduce una excesiva actitud literaria ante la vida” (11 y 13, énfasis mío). ${ }^{1}$

La displicencia piñeriana por publicar se contrasta con la propia actuación de Virgilio, quien comenzó su carrera de escritor dando a conocer, sobre todo, su poesía, y quien, posteriormente, continuó ensayando este género en silencio hasta su muerte, mientras anotaba con cuidado las fechas de sus poemas. Este interés continuado y silencioso de Virgilio por la poesía determina que el presente estudio

1 En relación con el reclamo de realizar una obra cerrada y concentrada véanse los ensayos piñerianos “Gertrudis Gómez de Avellaneda: revisión de su poesía” (1941) y "Poesía cubana del XIX”, texto del que no se conoce la fecha con exactitud. Léase el breve artículo "El país del arte” (1947) para ilustrar la crítica piñeriana frente al artificio y la excesiva pose literaria ante la vida. 
se concentre en reflexionar sobre la importancia de ésta dentro de su obra, pero no para jerarquizar el lugar que ocupan sus poemas dentro de toda su producción literaria. La poesía interesa aquí para aproximarnos a la conformación de una obra y una poética establecidas desde la poesía, dado el papel que la misma desempeña en las funciones que este autor le otorga a la imagen como instrumento no sólo dentro de la literatura sino de la cultura en general. Para ello se han seleccionado aquellos ensayos en los que Virgilio, especula sobre la palabra -que para él es siempre poética- y el vínculo de ésta con la imagen y la literatura. Entre estos sobresalen "El secreto de Kafka” (1945), "Freud y Freud” (1956), “Contra y por la palabra” (1969) y "Los dos cuerpos”.

\section{EL CONTEXTO DE UNA POÉTICA EXCLUIDA}

A los ya mencionados factores de índole personal externos e internos (la actitud piñeriana) a través de los que Arrufat explica el desinterés del poeta por publicar su poesía, debe sumarse la recepción que tuvo la obra piñeriana, que estuvo caracterizada por el ataque unánime de la crítica literaria y teatral de la época, de sesgo decimonónico. Quizás en este consenso de rechazo a los textos nuevos y rebeldes de Virgilio -o textos perversos, al decir del teórico francés Roland Barthes (1915-1980)- se halle alguna explicación de ese momento, difícil de fijar, en que Arrufat advierte el comienzo del paulatino desinterés del poeta por publicar su poesía (9). Es por esta razón que importan, en este ensayo, algunas circunstancias socioculturales nacionales-e internacionales-dentro de las que surge y se desarrolla la obra piñeriana, que se relaciona más con los escritores que se nuclean, primero en Espuela de Plata (1939-1941) y después en Orígenes (1944-1954), que con la primera vanguardia cubana que se reunía alrededor de la Revista de Avance (19271930). De hecho, tanto para los origenistas como para algunos escritores que se habían dado a conocer desde las páginas de la mencionada revista vanguardista, ésta había perdido su contenido de avanzada. ${ }^{3}$

\footnotetext{
Publicado en Poesía y crítica sin hacer constar la fecha en que fuera escrito.

3 Nótese que un vanguardista de la Revista de Avance, Alejo Carpentier(1904-1980), reclamarátambién a esta revista el haber perdido su carácter de impulso ("Un ascenso de medio siglo" 296). Entre los de la nueva promoción, la voz de Lezama Lima (1910-1976) ofrece una clara perspectiva crítica de dicha revista vanguardista -y de sus integrantes- al señalar que ésta "carecía de una línea sensible o de una proyección” y que esta nueva promoción no podía “mostrar filiación” con "hombres y paisajes que ya no tenían para las siguientes generaciones la fascinación de la entrega decisiva a una obra y que sobrenadaban en las vastas demostraciones del periodismo o en la ganga mundana de la política positiva” ("Respuestas y nuevas interrogaciones" 188). Por su parte, también crítico, Cintio Vitier (1921) resumirá que los resultados de la vanguardia en Cuba se manifiestan en las "superficiales cabriolas del efímero y desvaído vanguardismo cubano" como "en sus mejores consecuencias que se derivaron de su impulso: las llamadas poesía pura y social” ("La aventura de Orígenes" 309).
} 
Es con los origenistas que Virgilio comparte sus primeras publicaciones y muchas de sus actitudes ético-estéticas, entre las que sobresalen el rechazo a la promoción o vanguardia anterior y la necesidad de renovación del lenguaje, así como la urgencia de una reflexión más profunda del panorama poscolonial. Estos escritores y Virgilio pertenecen así a lo que Octavio Paz (1914-1998), en Los hijos del limo (1974), denomina como el fenómeno latinoamericano de vanguardia crítica, que rechaza de la primera vanguardia de América Latina el compromiso que ésta ha hecho con la política oficial, así como su inconsistencia estética. En contraste con aquella, ésta se preocupa por el logro de una obra concentrada y por la función del lenguaje no sólo como operación meramente estética. "Para aquellos jóvenes”, según Paz, "el lenguaje era, simultánea y contradictoriamente, un destino y una elección” (192, énfasis mío). Un destino y una elección dentro de los que sobresale, al decir de Paz en el mismo ensayo, la comprensión de "la poesía como el lenguaje original de la sociedad" (192, énfasis mío), aspecto que igualmente se traduce en Cuba como la aparición de la imagen preocupada por los orígenes; es decir, el momento de búsqueda de lo cubano a través de signos enraizados en la historia y caracterizados más por la permanencia que por la movilidad o por los cambios de la conciencia social.

Sin embargo, la dualidad credibilidad vs. incredulidad de Virgilio ante la literatura, que de algún modo señala Arrufat, incide también en la construcción de un sistema poético y cognoscitivo piñeriano que presenta, como uno de sus centros, esa misma poesía en la que se cree y se descree. Esta alternancia dual distancia y diferencia a Virgilio del discurso trascendente de los que integran Orígenes, a la vez que habla tanto de una actuación vital como de una realización estética cuya manifestación, en el plano del sujeto, revela su rebeldía a través de un comportamiento perturbador mientras su disposición, al nivel de la escritura, muestra una producción a caballo entre el modernismo estabilizador y el posmodernismo desconstructor. La coincidencia piñeriana entre textos rebeldes y conducta polémica crea un rápido contraste con otros origenistas como el propio Lezama Lima, Eliseo Diego (19201994) o Fina García Marruz (1923), por sólo citar algunos nombres, quienes se concentran en un trabajo más tolerante, acrático e, incluso, conciliador. Proceder éste que afectará también las cosmovisiones de estos intelectuales y viceversa, y que instaurará para Cuba, al decir de Cintio Vitier, "una atípica vanguardia, o, vanguardia sin vanguardismo" ("La aventura de Orígenes” 316). ${ }^{4}$

\footnotetext{
4 La conciencia de esta distancia de la vanguardia crítica cubana con la vanguardia en general determinará que Cintio Vitier instaure, al hablar de ese momento, el contradictorio término de atípica vanguardia o vanguardia sin vanguardismo para referirse a la vanguardia crítica cubana. Con este término, Vitier desea explicar, por un lado, que la suya no dejó de ser una vanguardia crítica; mientras que por el otro, señala que la misma adquirió un sentido de proyecto acrático. Véanse también al respecto los
} 
La incredulidad que lleva a Virgilio a desarrollar la idea de la destrucción le llega por medio de la sinonimia que éste establece entre poeta, vanguardia y rebeldía. Más consciente que otros escritores del período de la necesidad cultural del discurso de la rebeldía, “para Virgilio ésta es la experiencia de la cultura formal y metafísica como conciencia crítica del hecho social, para parafrasear a la teórica Julia Kristeva (1941) en Sentido y sinsentido de la rebeldía (Sens et non-sense de la révolte, 1996) (19). Tal entendimiento hará que Virgilio muy tempranamente señale, consciente, que le ha tocado "representar ese difícil papel de la rebeldía; del espíritu metódico y de intransigencia” (Virgilio Piñera en persona 89-80, énfasis mío). ${ }^{5}$ El rebelde se afirmará, por un lado, en la consideración de que la cultura es un acto de insubordinación y ésta, por ende, constituye un acto destructor y, por el otro, en la denuncia vanguardista del estado de parálisis del lenguaje de la sociedad moderna y, por supuesto, dentro de ésta, la cubana. ${ }^{6}$

Esta comprensión piñeriana de la cultura como una acción destructora objetivada a través de su estética es la que, a mi juicio, provocaría un consenso de recepción negativa por parte de la crítica literaria y teatral cubana. Muy a pesar del hecho de que alrededor de la década del cuarenta esta crítica se repartía en tres directrices principales y distanciadas (humanista/tradicionalista, marxista y origenista), los críticos de las tres tendencias respondieron de un modo unánime, primero, ante La isla en peso: obra poética ${ }^{7}$ y después en contra de Electra Garrigó, dos obras genéricamente diferentes -poesía y teatro- pero que comprendían lo cubano de manera semejante por medio de imágenes que expresan el caos y la destrucción. Esta recepción limitada y prejuiciada evidencia cómo tendencias exegéticas que se suponen diferenciadas pueden vincularse, y aún apoyarse entre sí, en el mantenimiento de un discurso ilustrado que consideran válido para el constructo de nación, cuando,

comentarios de Lezama Lima, quien expresa que la visita del poeta español Juan Ramón Jiménez (1881-1958) a la isla le dio a esta nueva promoción de intelectuales un sentido integracionista de la cultura ("Momento cubano de Juan Ramón Jiménez” 68) que, en realidad, está mucho más cercano al modernismo como movimiento espiritual que al vanguardismo como reacción consciente del papel del discurso de la rebeldía dentro de la sociedad.

5 En carta dirigida a Jorge Mañach a raíz de un ataque de éste a Poeta (1942-1943), cuaderno trimestral de poesía que Virgilio fundara tras su ruptura con Espuela de Plata, ante la ortodoxia religiosa de sus editores. El documento constituye una defensa coherente de dicho órgano.

6 Los textos publicados en Poeta son elegidos cuidadosamente como respuestas a la estética dominante y, sobre todo, a la religiosidad de los editores de Espuela. No debe obviarse que desde estas páginas se da a conocer “Oración y poesía”, extraído de Foyers d’Incendie (1938) de Nicolás Calás. En este texto, Calás ataca la intención de Herbert Read de reconciliar arte y religión y afirma: "La poesía es deseo de conquista, mientras que la oración expresa una huida del objeto. El artista, el poeta, son revolucionarios, pero el creyente permanece fundamentalmente reaccionario, a pesar de las apariencias a menudo contrarias” (n.pag.).

7 En cursivas cada vez que se refiere a la publicación del poema en forma de plaquette o separata. 
en realidad, la pulsación internacional e hispanoamericana ha entrado de lleno en la modernidad. La receptividad que recibe Virgilio pudiera resumirse, en términos generales, a partir de la reseña de Vitier acerca de "La isla en peso", en la que éste afirma que la expresión de Virgilio significa "el demonio de la más absoluta y estéril antipoesía” (Poesía y prosa 59). Dicha postura crítica señala no sólo el comienzo del proceso de marginación de un poeta, sino la insuficiente latitud de la crítica para entender el advenimiento de lo nuevo -y su necesidad-, en este caso de la antipoesía que, una década más tarde, tendrá su auge en América Latina en la figura del chileno Nicanor Parra (1914), que en 1954 publicará Poemas y antipoemas. ${ }^{8}$

Indistintamente, y localizadas ante el debate de la construcción de la nación, cada una de estas hermenéuticas cerraron fila al afianzar discursos culturales y políticos trascendentes y tradicionales, que alientan para el caso cubano un destino desconocido pero luminoso, muy diferente a la imagen nueva que Virgilio revela de Cuba como espacio de asfixia. El resultado de esta actitud hegemónica se traduce en el enajenamiento sociocultural del discurso de la rebeldía y, por supuesto, de sus productores. Con la distancia que proporciona el transcurso de más de medio siglo, se puede decir que la dominancia de estos grandes discursos dentro de las letras cubanas tiene varios efectos. Se registran los discursos ilustrados que la ideología dominante valida y utiliza para rechazar, marginar y excluir. Tales excusas políticas y culturales señalan la pérdida de la autonomía del intelectual que al responder a estos mecanismos discursivos se adhiere al lenguaje oficial de un modo consciente o inconsciente, bien sea siendo parte de las estructuras de poder, bien estando fuera de ellas. Finalmente, este ejercicio crítico incidirá en la paulatina conformación de una literatura tradicional que, salvo algunas excepciones, se encuentra mucho más relacionada con la búsqueda de la escritura dentro de una página en blanco que con el carácter representacional de la misma.

8 Para una comprensión de lo que denomino como una unánime recepción crítica ante la obra de Piñera, véanse algunas de las críticas que Virgilio recibiera a raíz de la publicación de La isla en peso: La estudiosa marxista Mirta Aguirre (1912-1980) reconoce que la poesía de Virgilio significa "un cambio de rumbo, el inicio de un camino", pero insiste en que éste es "un poeta ofuscado por las frutas que se pudren en el lecho de los ríos" y que en su percepción de Cuba es apenas un "poeta que comienza a verla” (La isla en peso: obra poética 30). En 1944, en Orígenes, el crítico origenista y religioso Cintio Vitier reseña la publicación de Poesía y prosa y expresa que "este libro de Virgilio Piñera podrá ostentar en todo caso el honor de haberse enfrentado, para delatarlo y ceñirlo insuperablemente, con el vacío inasible y férreo que significa para nosotros, a través de nuestra cotidiana experiencia metafísica, el demonio de la más absoluta y estéril antipoesía" "Virgilio Piñera: Poesía y prosa" 47-59). En el mismo año de 1944, en el Anuario Cultural de Cuba aparece un comentario de otro miembro de Orígenes, Gastón Baquero (1918-1996). Éste dice que La isla en peso “viene a aportarnos una de las tendencias extremistas, negativistas, deformadoras intencionadas de nuestra realidad" (“Tendencias de nuestra literatura” 279). 
UNA POÉTICA DE LA IMAGEN

El temprano desencanto de Virgilio del valor de la literatura que, como señala Arrufat, lo llevaba a descreer de la poesía y del poeta determinaría la actitud polémica y extrema de Virgilio Piñera contra y por la palabra. Sujeto de posiciones extremas, Virgilio, como los escritores Severo Sarduy (1937-1993) y Barthes, señala la vinculación entre texto y cuerpo. ${ }^{9}$ Éste descree así del cuerpo de la literatura al reaccionar frente al cuerpo de algunos literatos o, en palabras de Arrufat, frente "al artificio y las falsedades a los que conduce una excesiva actitud literaria ante la vida” (13). Su desencanto lo conduce, ciertamente, a descreer pero también a elegir dos héroes literarios, Dante y Kafka, a la vez que asume una postura en la que él, Virgilio Piñera, se considera un mártir de la palabra.

Este martirologio se revela de algún modo en su ensayo "El secreto de Kafka”, en el que Virgilio expresa que "el mundo se divide en dos grandes mitades si lo miramos desde el ángulo de la personalidad: el de los que tienen fe y el de los que dan fe":

Los primeros, por su condición de creyentes, no pueden dar fe de esta fe (la limitación para esto es su fe misma), que sería dar cuenta de la marcha del mundo; los segundos no podrían tenerla porque precisamente sólo sirven para dar fe de esa marcha del mundo. Los primeros reciben el nombre de seres humanos; los segundos el de artistas. (104)

Virgilio prefiere apuntar que este darfe de alguien como Kafka, cuyo secreto, en su opinión, consiste en haber sido estrictamente un literato, se "verifica estrictamente por medios puramente literarios; es decir, mediante enormes arquitecturas de imágenes” (104). Sin embargo, hay también en esta división piñeriana una coincidencia con la distinción hecha por la filósofa española María Zambrano (1904-1991). Para ésta, en "Franz Kafka, mártir de la miseria humana”, hay una clase de escritores que lo son “contra sí mismos” a la que pertenece, por supuesto, Kafka. Estos escritores, según la pensadora, “son los mártires, los llamados a dar testimonio [...] de terrible obscuridad; no de una revelación, sino de una destrucción siniestra”. Son mártires de su testimonio, remata Zambrano, porque lo que les "tocó descubrir era la sordidez humana, la miseria más extremada, el desamparo, la humillación”, y gracias “a estos mártires hoy podemos ver el cáncer que corroe a Europa” (3, énfasis mío).

\footnotetext{
9 En Escrito sobre un cuerpo (1964), el narrador y teórico cubano considera "todo lo escrito y por escribir como un solo y único texto simultáneo en que se inserta este discurso que comenzamos al nacer” (66).
} 
Virgilio Piñera puede ser considerado uno de esos artistas que dan fe de la marcha del mundo o uno de esos mártires de la palabra que, al decir de Zambrano, dan fe de la destrucción. ${ }^{10}$ Su posicionalidad en contra de sí mismo fija su estar contra la palabra para dar fe o testimonio, y su preocupación por la parálisis del lenguaje y/o la sociedad le hacen situarse, a la vez e irónicamente, a favor de ésta, al validar medios puramente literarios que resume con la frase enormes arquitecturas de imágenes, proveniente de "El secreto de Kafka". Para Virgilio estos medios literarios no apelan a la "ofensiva teoría del arte por el arte ni tampoco a la verdad perogrullesca de que si la forma no es artística la obra no vale como tal”(42). Se trata, por el contrario, según este autor, "de demostrar que en el campo de lo estrictamente literario el único móvil del artista es producir, a través de una expresión nueva, ese imponderable que espera todo lector y que se llama la sorpresa literaria, la sorpresa por invención" (42). Esta conciencia autoral resultaría en una literatura en la que el autor y el lector interactúan a través de la reflexión o del descubrimiento que propone el texto y que se establece por medio de la imagen por sorpresa.

La imagen, dentro de esta poética piñeriana, se constituye en un instrumento de lo nuevo y lo destructor, y esta capacidad es la que le permite destruir e impactar sobre los discursos sociales homogéneos. Para esta realización destructora, Virgilio le asigna a la imagen funciones específicas que permiten establecer analogías -conscientes e inconscientes- del pensamiento piñeriano con autores como Barthes, ya mencionado, el filósofo Ludwig Wittgenstein (1889-1951) y el padre del psicoanálisis, Sigmund Freud (1856-1939), al que Virgilio se acerca de manera análoga a los posmodernistas, para quienes, como sugiere John Wilcox, lo estimulante son las reflexiones de Freud de 1919 sobre la extrañeza o lo uncanny (unheimlich) (Self and Image 1).

El SECREto de KafKa. ¿'Y El de VirgiLio?

La primera función de la imagen como instrumento desconstructor se refiere a la relación que ésta establece con el lenguaje pensado como texto o cuerpo y el goce, relación en la que el concepto de la imagen por sorpresa (o la imagen nueva) desempeña un papel de importancia dado que la imagen por sorpresa (o la imagen nueva) es la que facilita la construcción de un texto (cuerpo) rebelde y/o perverso, como advierte Barthes en El placer del texto (Le Plaisir du texte, 1973).

\footnotetext{
${ }^{10}$ No resulta casual que en una carta a su amigo y antagonista literario, Lezama Lima, Virgilio expresa que el único tema que “me interesa es mi teoría de las destrucciones", a la par que enfatiza que "si queremos ver claro en mi poesía [o literatura] habrá necesariamente que partir de una palabra: $l o$ tumultuoso" (“Cartas de Virgilio” 272-73, énfasis mío).
} 
La segunda función se instaura a partir del vínculo entre imagen, performance y conocimiento. En esta relación el juego, o la fricción con la realidad, actúan como elemento vital e infinito sobre el cual se produce el performance del texto. $\mathrm{Y}$ el activo performance del texto (o del cuerpo) es el medio a través del cual el sujeto humano puede o bien entrar en contacto con alguna forma de conocimiento o certeza o bien incidir contra la parálisis del lenguaje, una idea que aparece en Sobre la certeza (Über Gewißheit, cuyos textos fueron escritos por Wittgenstein entre 1949 y 1951 y publicados por primera vez en 1969). Finalmente, la tercera función describe la operación de la imagen como agente de lo uncanny, cuyo objetivo es relatar un fenómeno desconocido y aun familiar, pero posiblemente vivo como secreto reprimido. Virgilio se apropia del concepto freudiano desarrollado en "The Uncanny” (1919) no sólo para expresar lo negativo, sino también como noción que se adecua a su objetivo de que la imagen uncanny está capacitada para transmitir y destruir ciertas realidades.

Dentro de la primera función la imagen como agente destructor adquiere también un valor performativo, dado que su acción revela las restricciones sociales y obsoletas que enfrenta el sujeto humano. Dentro del proceso que se opera entre el texto y el lector, el texto escrito deviene un mecanismo de representación que, en el sistema piñeriano, significa una desconstrucción sobre lo concreto y lo real. Este performance de la imagen, para Virgilio, asegura la recepción de lo sorprendente en todas las épocas, ejemplificada a través de los casos de los ya mencionados Dante y Kafka. Del primero, según Virgilio, la imagen por sorpresa no se encuentra en la asombrosa erudición que recorre la Divina Comedia, sino en la "proyección de embudos, de un purgatorio en rampas y un paraíso movido por esferas". Del segundo, la creación de "imágenes, de juguetes de imaginación [...] los corredores interminables y cambiantes de la mansión de Klara (América) o las 'chiquillas guardianes' del cuarto del pintor (El proceso)” (“El secreto de Kafka” 231).

Emergen aquí dos tópicos: el primero, la realización por medio de la imagen de textos que pueden ser leídos también de una manera ahistórica ya que producen "a través de una expresión nueva, ese imponderable que espera el lector y que se llama sorpresa_iteraria” (231, énfasis mío). El segundo, el nacimiento del sujeto a través de la imagen que lo descubre al penetrar y actuar dentro de lo desconocido. ${ }^{11}$

La primera postura defendida por Piñera en la década del cuarenta se encuentra relacionada a la vez con la defensa de la autonomía del trabajo artístico y la "atopía" de su carácter, es decir, su no pertenencia a un lugar ni tiempo específico, ya que

\footnotetext{
${ }^{11}$ Las coincidencias son comunicantes, ya que Dante es también el escritor elegido por Joyce y
} Wittgenstein. 
a alguien que no la haya leído [la Divina Comedia] le sucederá lo mismo que al primero de los lectores de Dante: se sentirá colmado, inundado mediante el extraño método de la sorpresa por invención (en este caso literaria). Y no será por cierto esta sorpresa ni el fondo ético de la Comedia, el platonismo que alienta en ella ni la asombrosa erudición que la recorre. Se verá sorprendido por la invención de Dante de un infierno que se proyecta en embudos, de un purgatorio en rampas y un paraíso movido por esferas. Y no se detendrá ni un momento en las ideas que dichas metáforas sustentan -o que dicen, jay!, sustentar sus hermeneutas de seis siglos- de pecado y salvación. Esta será la prueba más correcta de que el móvil último que moviera a su autor fue el de una invención estrictamente literaria, producida por una enfermedad que se llama literatura, como la de la seda del gusano o la de la perla de la ostra. (231, énfasis mío)

Roland Barthes llamará la atención sobre este asunto en la década del sesenta al afirmar que el texto "es atópico, si no en su consumo por lo menos en su producción”, así como que “de esta atopía el texto toma y comunica a su lector un estado extraño: simultáneamente incompatible y calmo” (El placer del texto 41). El estado de extrañeza en que, según Barthes, se realiza la lectura, induce a pensar, dentro del sistema piñeriano, que el consumidor, o lector del texto, retiene algo de este carácter atópico, al menos, la distancia de aquél, su disociación interpretativa, o la insistencia, para Virgilio, de la imagen rara que crea ese estado disociativo en el receptor. Para Virgilio, ese estado de extrañeza en que se realiza la lectura se corresponde con el estado de goce en el lector que, además, precisa ser un lector activo, impelido a pensar a través de lo nuevo que la imagen artística propone: "Por eso los primeros [los lectores] gozan tanto cuando se ven transformados por el artista en entes imaginarios, en personas despersonalizadas" ("El secreto de Kafka” 230).

$\mathrm{Al}$ efecto nuevo, o sorpresa literaria, le corresponde entonces una necesidad intrínseca. Así, el goce estético no se produce sin este elemento sorpresa que transmite el estado de lo raro, de lo extraño. Extrañeza y goce se encuentran tan vinculados como extrañeza y posibilidad de pensamiento. Esta vinculación indica la posibilidad copulativa del goce y el pensar, así como el condicionante de uno en el otro. Al mismo tiempo estas relaciones operan dentro de una relación de causalidad, cuando el consumidor se ve "transformado" en "entes imaginarios" o en "personas despersonalizadas", estadios todos señalizadores de distintos estados metamórficos del sujeto. El goce, entonces, se produce dentro de una atopicidad atemporal que conduce, de cualquier manera, a través de las infinitas proporciones de la ficción y la invención, a la búsqueda y problematización de la identidad concreta y metamorfoseada y de la trascendencia artística.

La extrañeza, en el sistema piñeriano, se convierte igualmente en una necesidad. La actuación de la misma no sólo da paso a la desfosilización del pensamiento, 
sino que posibilita al sujeto actuar sobre el conocimiento siempre subjetivo y múltiple como el propio individuo, por ende fragmentado. Este proceso de protesta o negación, cuya realización opera a través de la imagen y se concreta en la palabra escrita, anuncia la rebeldía misma de la palabra -y del sujeto- que se resiste a ser leída/o pasivamente y que reclama ser reinterpretada/o.

En la literatura de Virgilio, la imagen por sorpresa se encuentra no sólo en los múltiples cuerpos dobles y/o fragmentados que recorren su obra, sino en la conciencia de que la literatura se iguala a una cámara que enfoca su lente dentro de lo real que ha sido marginado y excluido. $\mathrm{Y}$ en este trabajo de transmisión nuevo que produce imágenes nuevas radica la sorpresa de la revelación de lo real. Ya en el preámbulo a sus Cuentos fríos (1956), Virgilio explica que éstos son fríos “porque se limitan a exponer los puros hechos” (7, énfasis mío). Posteriormente, en una entrevista sobre la frialdad de su narrativa, amplía su explicación a partir del brevísimo cuento “En el insomnio”, del que dice:

Me limité a lo que, grosso modo, puede llamarse "la atmósfera” en que vive y reacciona un hombre que no logra conciliar el sueño. No me interesaba la sicología del personaje sino la situación en la que se encontraba. Ahora se habla del "nouveau roman” y hace rato que yo lo venía haciendo en mis cuentos. (Virgilio Piñera en persona 144, énfasis mío)

La exposición de los puros hechos vincula a Virgilio con la idea dela construcción del lenguaje como objeto en cuyo propósito se encuentra lograr un producto casi objetivo. Como si fuera poco con el preámbulo, en el primer párrafo del cuento "El muñeco”, perteneciente a la colección mencionada, Virgilio reflexiona sobre el proceso de la escritura:

Soy nada más que un inventor de artefactos mecánicos. Si desciendo ahora a escribir es precisamente porque no he podido idear el artefacto que exprese los horribles hechos que paso en seguida a exponer. Si la literatura logra transmitirlos, pensaré que también ella es otro artefacto. (151, énfasis mío)

Resulta interesante anotar cómo en estas breves líneas Virgilio vuelve a hacer coincidir dos asuntos: los medios literarios y el sentido de sacrificio o martirologio del artista que desciende a dar fe descreído. Esta actitud de descreimiento -posible teísmo si no ateísmo- facilita en el artista el logro de una mirada crítica o una acción movilizadora del lenguaje. Y éste, entonces, por su capacidad marginal y crítica, contiene en sí el relato crítico o extraño como condición de la atopía que se desplaza al texto y viceversa: el texto se desplaza al lugar del autor convertido en un no-lugar y un no-tiempo. 
Ahora bien, los medios literarios que Virgilio llama artefacto recuerdan la relación que establece la modernidad entre el poema como objeto u artefacto que es suficiente en sí mismo y el artista o artesano que conoce su oficio y que sólo se expresa de una manera aparente en estas palabras. La utilización por Virgilio, sin embargo, del condicional en dos oraciones seguidas, por una parte, pone al lector sobre aviso de la insuficiencia del artista como inventor y de la literatura como artefacto. Por otra parte, Virgilio señala el primer significado que ofrece el Diccionario de la Lengua para la palabra artefacto: “como obra mecánica hecha según arte” (219). Esta significación, según el diccionario, apuntala también la naturaleza mecánica del lenguaje y su capacidad a la par de rebeldía y experimentación. Recuérdese que la palabra artefacto alude tanto a la "carga explosiva, mina, petardo, granada" como a "los experimentos biológicos, formación producida exclusivamente por los reactivos empleados y perturbadora de la recta interpretación de los resultados obtenidos” (219). El artefacto literario u objeto de arte no es otra cosa que un objeto mecánico (o una máquina lingüística) cuya función es exponer los_puros hechos. La literatura como artefacto aparece entonces tras una envoltura en la que se mezclan ideas tales como invención-inventor, mecánica, rebeldía, experimentación y deseo de objetivación. El que la imagen revele puros hechos posibilita, según Virgilio, comprender la mecánica del lenguaje y expresar, al revés, pero como un hecho posible, lo que se creía imposible. En otras palabras, la actuación del sujeto transforma los discursos y, al transformarlos, no sólo se transforma a sí mismo, sino a aquello que lo rodea.

CONTRA Y POR LA PALABRA

La segunda función de la imagen que se instaura a partir del vínculo entre ésta, performance y conocimiento se encuentra desarrollada a través de toda la obra piñeriana pero, sobre todo, en el ensayo “Contra y por la palabra”, escrito a más de veinte años de "El secreto de Kafka”. En éste, Virgilio hace un resumen de las ideas que ha desarrollado durante toda su producción literaria, por lo que resulta lógico que comience dicho ensayo al exponer, una vez más, tanto el tópico de la imagen convertida en agente destructor como el tema de la parálisis del lenguaje. Estos dos asuntos le permiten ofrecer su comprensión del lenguaje que, paradójicamente, no ha dejado de considerar a la poesía.

"Contra o por la palabra” bien pudiera haberse titulado "Contra o por la poesía”, si se considera que, para Virgilio, el lenguaje nace del acto poético, una afirmación que lo emparenta tanto con el trabajo de Paz como con el de Wittgenstein. Por esta época, el primero afirma que "el lenguaje es en su esencia una operación poética que consiste en ver al mundo como un tejido de símbolos y de relaciones entre esos 
símbolos” (Los hijos del limo 89). Un poco antes en el tiempo, el segundo sugiere que el lenguaje es poético (imagen), dado que "no ha surgido de un razonamiento" y añade que "el concepto de saber se ajusta al de juego de lenguaje" (Sobre la certeza 476 y 566). Un juego, además, que se establece en la fricción (uso del lenguaje) del sujeto con la realidad. Al defender la idea de que el lenguaje y la palabra son sinónimos, Virgilio coincide con estos pensadores ya que ésta es, para él, fundamentalmente “figura del pensamiento” (267, énfasis mío). De estas uniones resulta otra relación entre palabra y figura del pensamiento en lugar de forma material del pensamiento.

En el sistema piñeriano, la denominación palabra poética es sencillamente una redundancia, porque la palabra, para él, es siempre figura, es decir, traslación de sentido, poesía. El nacimiento del lenguaje mismo dentro de esta perspectiva se ha originado en las lindes del acto poético. Como no hay lenguaje sin palabra, sigue explicando el ensayista, se sobreentiende que ésta se origina en el mismo proceso poético de asociaciones, sea por comparaciones, oposiciones, adiciones o sustracciones de significado. La palabra para ser tiene que ser poética, ya que siendo poética (o siendo palabra) es que cumple su función cognoscitiva de nombrar, asociar significados o ampliarlos. La relación entre palabra, poesía y pensamiento es apretada. La palabra piñeriana se realiza por la conciencia de la imaginación y la relación que ésta sostiene con el sujeto. Si la palabra o el pensamiento del sujeto no está cargada/o de imágenes, es palabra muerta, es decir, pensamiento muerto.

"Contra y por la palabra" se incia a través de combinaciones y ejercicios vanguardistas con la palabra o con la poesía, ya que ambas son idénticas en este ensayo que resume la poética del autor. Tales asociaciones, a la vez, conducen a Virgilio a la siguiente idea: la palabra no hace al sujeto, es el sujeto el que hace la palabra, la construye o la destruye. En consecuencia, el lenguaje expresa la actividad de lo que el sujeto da cuenta. El resorte mediador entre uno y otro es el acto mismo o la activación que del lenguaje hace el sujeto. Virgilio afirma: "La palabra no fue dada al hombre, la palabra es una creación del propio hombre” (266) y añade que es la figura del pensamiento. Así, éste expresa, por un lado, que una figura no es otra cosa que la palabra poética capaz de expresar el pensamiento, y por otro lado, que la misma es una construcción del sujeto, a través de la imaginación. El sistema piñeriano señala que el pensar se constituye por medio de dos experiencias complementarias, ya que una determina la posibilidad de la otra: la experiencia poética a través de la cual se accede a la experiencia constructora y la experiencia constructora por la cual se construye un lenguaje poético capaz de transmitir revelaciones o verdades concretas.

Deesta manera, existe dentro del pensamiento piñeriano una relación de igualdad entre pensamiento, palabra y figura que señala un sujeto capaz de construir por medio 
de la imaginación. Si se acepta esta premisa, la imaginación significa entonces el instrumento por el cual el sujeto se realiza como tal. La relación establecida por Virgilio parece casi un teorema matemático, ya que, al comprender la imaginación como agente activo de la construcción del pensamiento, el crítico trae a colación la necesidad de que la palabra refleje imágenes.

Al defender el carácter activo de la imaginación del sujeto en la construcción del lenguaje, no sólo se observa que la forma del sujeto piñeriano se encuentra en su imaginación, sino también que magia, imaginación e imágenes potencian en el individuo una actitud y una acción de autoreconocimiento. De manera similar a Virgilio, Paz afirma en el mencionado ensayo que "este hacer es sobre todo un hacerse a sí mismo", ya que "la poesía no es sólo autoconocimiento sino autocreación. El lector, a su vez, repite la experiencia de autocreación del poeta y así la poesía encarna en la historia” (92). Detrás de esta idea se halla, en palabras del crítico, la modernista y también "antigua creencia en el poder de las palabras: la poesía pensada y vivida como una operación mágica destinada a transmutar la realidad" (92).

Si el pensamiento (palabra-figura) no expresa una imagen, se asiste, en palabras de Virgilio, a la acumulación de las palabras muertas "que nos vemos obligados a seguir usando por no disponer de otras”, y que para él causan la petrificación del pensamiento. A palabras muertas corresponden pensamientos muertos y, a su vez, "el pensamiento muerto genera un lenguaje muerto" ("Contra y por la palabra" 266). No se hace esperar la funcionalidad de la imagen como agente de relación entre lenguaje y sujeto. Dado que la palabra, dentro de la concepción piñeriana, tiene una relación de complementarios con el sujeto, y éste con su capacidad de imaginación, la palabra (o figura) nace, esplende, declina y muere, como el sujeto según este ensayo de conclusiones (266).

Para Virgilio, uno de los conflictos a los que se enfrenta el sujeto es la existencia de palabras muertas que por haber pasado a formar parte de un lenguaje obsoleto no expresan. Este lenguaje obsoleto, según Virgilio, ha dado paso a la construcción de un mundo aparencial, uno de los dilemas de la modernidad, una realidad virtual, al decir de los posmodernistas. Para él, la modernidad misma se construye sobre un mundo de apariencias, en tanto el lenguaje que la expresa carece de sentido -ha dejado de ser o significar-, y propone, así, el término babelismo para designar lo que él entiende como la extenuación de la palabra. Dicha extenuación opera, de acuerdo con las opiniones que expresa en "Contra y por la palabra", sobre la base de una paradoja, ya que, según Piñera, el enriquecimiento de la palabra que ha traído el lenguaje científico, por una parte, y, por otra, la correspondiente acumulación a través de la historia del lenguaje y su utilización son, justamente, signos de la extenuación del lenguaje: 
A primera vista parecería que el lenguaje estuviera más vivo y actuante que nunca. Los incesantes avances de la cibernética y de la astronáutica (por no citar más que dos de las nuevas tecnologías) han incorporado al lenguaje nuevos términos y palabras. Pero este enriquecimiento del lenguaje es, paradójicamente, signo de su extenuación. Un lenguaje que en el momento presente se encuentra en su etapa de fosilización, habiendo alcanzado el punto más alto en su desarrollo, ha dejado, por su misma funcionalidad, de ser operante. Y cuando un lenguaje se hace inoperante, deja de ser un medio de comunicación entre los hombres. Hoy día padecemos de babelismo, enfermedad de la que pocos se percatan, a todos consume. Para que nuestra vida cambie (por inoperancia del lenguaje nuestra vida es sólo aparencial) debemos consecuentemente cambiar el lenguaje, y cambiarlo para desbabelizarlo. Se impone pues una desfosilización del pensamiento. (267, énfasis mío)

La modernidad se revela para Virgilio como un mundo aparencial en el que el lenguaje -que es también el sujeto- se convierte en un "cuerpo opaco” (266), dado que no proyecta una imagen o, aún más, no ofrece la posibilidad de crear imágenes. La imagen, como cualquier retórica, se desgasta también por el uso de las convenciones sociales. Y la incapacidad del lenguaje para crear imágenes señala asimismo su carencia de sentido y, por ende, de pensamiento. Así, para Virgilio el sujeto contemporáneo no expresa su pensamiento sino que repite un lenguaje acumulado, establecido y oficial, en el cual no ha intervenido el agente activo de la imaginación del individuo. La no intervención del sujeto en la construcción de la palabra muestra la relación ajena que éste sostiene con el mundo que le rodea, lo cual provoca las evidencias de esta muerte a través de los signos de la incomunicación y la enajenación.

Para Virgilio, la literatura -y el arte en general- tiene la capacidad de crear imágenes, y por esto se convierte en el medio a través del cual las imágenes cumplen sus funciones como agentes que revelan tanto la fosilización del pensamiento como la del sujeto. El trabajo incesante de las imágenes como método artístico o instrumento facilita comprender su operación como agentes destructores o desfosilizadores, también llamados por Virgilio desbabelizadores. Dentro del trabajo desfosilizador, el crítico acude al desarreglo de los sentidos propuesto por el poeta francés Arthur Rimbaud, a la técnica surrealista de la desautomatización de los sentidos y al trabajo del también francés Antonin Artaud, poeta y dramaturgo que hablara sobre la prioridad del lenguaje de los gestos sobre el lenguaje de las palabras (268). En un ensayo complementario sobre el dramaturgo francés Alfred Jarry, Virgilio valida el lenguaje coprológico (perteneciente o relativo a la coprología, es decir, al estudio de los excrementos sólidos) presente en el drama Ubú rey (Ubu roi 1896) como signo de insubordinación transgresiva, ya que lo nuevo de este discurso se 
encuentra en su localización social que lo aísla y, por ello, en la capacidad activa de soliviantar a la vez al espectador y la adocenada forma de vida burguesa (“Alfred Jarry 'joven airado'” 216). ${ }^{12}$

Contrariamente a lo que podría pensarse, la concepción del lenguaje como una operación poética no implica idealidad sino la validación piñeriana de todas las proposiciones en las que la imaginación es un agente activo y (des)constructor dentro de la realidad. La necesidad de desfosilizar el pensamiento a través de la palabra-figura nueva (imagen nueva, poesía) conduce a la formación de una expresión estética. Esta expresión comienza en el límite de la crisis de la palabra y de los discursos religiosos, morales y políticos; allí donde la palabra, por simple, no parece ya desatar ninguna imagen, ninguna visión, justo en las lindes de la palabra de todos los días.

\section{FREUD Y VIRGILIO Y LA IMAGEN UNCANNY}

La tercera y última función, como se ha anunciado, es la operación que realiza la imagen extraña o uncanny. Esta operación de la imagen se encuentra vinculada tanto con la idea de la imagen como agente destructor como con la imagen en su calidad de performance. La utilización del concepto freudiano de lo uncanny es decisivo en el estudio de esta función de la imagen como relato de un fenómeno desconocido y aún familiar, pero posiblemente vivo como secreto reprimido. De este modo, Virgilio no sólo se apropia de lo uncanny como un concepto que expresa lo negativo, sino también como noción que se adecua a su objetivo de que la imagen uncanny opere como una suerte de destrucción de ese mundo secreto a través de la insistencia en figuras que, en muchos casos, se corresponden con lo abyecto o lo inexplicable que reclama una interpretación. El descubrimiento de ese mundo reprimido añade a la imagen uncanny un contenido de certeza que se amplía y cobra fuerza dentro del terreno de la literatura, ya que el propio Freud le otorga a la ficción la posibilidad de mayor creación de figuras de este tipo. La relación entre la imagen por sorpresa y la imagen extraña se basa, sobre todo, en que el extrañamiento que provoca la imagen por sorpresa, extraña o uncanny es lo que revela al sujeto un

12 Véase al respecto el estudio de David Inglis ASociological History of Excretory Experience (Defecatory Manners and Toiletry Technologies) para un resumen histórico y sociológico de las costumbres de excreción humana a través de diferentes épocas, así como la comprensión que en diferentes períodos históricos se ha tenido sobre el tema y que pasa, en lo fundamental, por la visibilidad y tolerancia del sujeto de la imagen y el olor de la excreta. Visibilidad y tolerancia que disminuyen en la misma medida que se consolida la idea de un modo o estilo civilizado. Un proceso que se desplaza de la tolerancia y la visibilidad a la intolerancia e invisibilidad de la excreta en la sociedad moderna, o más propiamente burguesa (xii). 
conocimiento sobre sí y su realidad identitaria. La extrañeza en el sistema piñeriano se convierte igualmente en una necesidad, ya que a través de ésta el sujeto actúa sobre el conocimiento siempre subjetivo y múltiple como él mismo.

Luego de buscar en las referencias bibliográficas de Virgilio resulta seductor el hecho de no haber encontrado en ellas un indicio de sus lecturas sobre "The Uncanny”, cuando, curiosamente, existe una reseña de Virgilio, titulada "Freud y Freud”, sobre La interpretación de los sueños (1900). ${ }^{13}$ Todo parece indicar que Virgilio llegó a la idea de la extrañeza freudiana a través de sus medios literarios. En la breve reseña "Freud y Freud” existe una especie de complementación temática a “El secreto de Kafka”. En ésta, Virgilio defiende la idea de que, al igual que sucede con Dante y Kafka, el valor transgresivo y futuro del discurso freudiano se encuentra en la (re)creación o (re)construcción de imágenes con las que el psicoanalista ha instrumentado su análisis científico. La aclaración al lector viene rápido por parte del ensayista: "No quiero decir que Freud va a quedar como destacado autor de obras de ficción y tampoco que su interés dentro de cien años radicará en su elevado estilo literario”, sino que, continúa explicando, la fantasía poderosa de este hombre "lo sitúa entre los grandes artistas de todas las épocas, lo lleva con poderes de brujo a la construcción de un mundo que al par que implacablemente lógico es también implacablemente ilógico” (278). Y argumenta esta posición:

¿Quién no recuerda, por ejemplo, su celebérrima interpretación de los sueños? Si un sueño ya es de por sí pasmoso, mucho más pasmosa será la interpretación que Freud nos da del mismo. Es decir, que a medida que vamos leyendo la interpretación freudiana de un sueño, al mismo tiempo que Freud nos descubre el mecanismo de la vida onírica, va desplegando ante nuestra vista otro sueño: la interpretación del sueño por él estudiado. Y dicha interpretación, por el hecho de haber sido presentada como un sueño, exige a su vez ser interpretada. Aquí, como sucede en el arte, la estatua es más acabada y compleja que el modelo. (278) ${ }^{14}$

Como literato, para Virgilio el atractivo freudiano se encuentra en la relación recíproca entre el relato y la imagen, y su concreción -o fusión- como relatoimagen. El sueño, para ser expresado, necesita del relato y de la imagen. La

${ }^{13}$ La interpretación freudiana de Virgilio se realiza a partir de su lectura de Introducción al psicoanálisis, que apareció en Madrid en la Editorial Biblioteca Nueva en 1948 y que Virgilio eligió reseñar.

14 De la misma edición cita el siguiente comentario del psicoanalista como uno de los momentos de mayor capacidad freudiana de construcción de imágenes: "Recordaréis aquí sin esfuerzo alguno los símbolos empleados. Los órganos genitales masculinos se hallan representados por la reunión de tres personas, y los femeninos, por un paisaje compuesto de una capilla, una montaña y un bosque. Los escalones que dan acceso a la iglesia constituyen un símbolo del acto sexual, y aquello que en el sueño aparece como una montaña lleva en anatomía el mismo nombre: Monte de Venus” (278). 
traducción científica del mismo se vierte a un relato a través de otras imágenes. Y esta producción (re)creadora incesante del lenguaje interior del sujeto provoca, en su interpretación, otras narraciones en las que la imagen continúa siendo la figura principal. El relato-imagen no sólo comunica lo desconocido y extraño, sino que al ser explicado ofrece sucesivas metamorfosis, al mismo tiempo que preserva la esencia de permanecer como relato o narración, pero siempre como imagen.

El propio Freud, en “The Uncanny”, le concede un lugar especial al escritor de ficción y al mundo en el que éste trabaja, donde se producen para el psicoanalista las variaciones de lo uncanny como un resultado paradójico: "in the first place a great deal that is not uncanny in fiction would be so if it happened in real life; and in the second place that there are many more means of creating uncanny effects in fiction than there are in real life” (150, énfasis mío). La paradoja anunciada señala en lo uncanny una esencia descubridora, dado que la posibilidad de haber sucedido en la vida real es lo que convierte en extraño o uncanny a algo que dentro del mundo de la ficción era aparentemente parte de un elemento más de la fantasía. La lectura inversa que la vida real hace de este elemento fantástico, nuevo o imaginativo, es la que lo hace entrar en el terreno de lo extraño, con lo cual Freud advierte que existe un lector para el cual estas imágenes operan dentro de la extrañeza al develarle un mundo desconocido o familiar pero secretamente reprimido.

En este ensayo, Freud relaciona el término con sentimientos e impresiones del sujeto ante algún fenómeno cuya naturaleza tiene varias caras, ya que, por un lado, señala lo desconocido y extraño (no familiar), mientras que, por otro lado, el término se relaciona con algo secretamente familiar que yace en el lenguaje de lo reprimido, lo cual, en algunas ocasiones, permite descubrir la otra cara extraña que se horroriza ante algo sabido pero escondido. El fenómeno revelador de lo uncanny, asimismo, se relaciona en general y en la mayoría de los casos con circunstancias y objetos que tienden a crear sentimientos de repulsión y angustia, y se vincula con el tema del doble -una constante en la narrativa piñeriana- que, según Freud, "was originally an insurance against the destruction of the ego, an 'energetic denial of the power of death'”, pero que en su aspecto reverso se convierte también en un heraldo o presagio de la muerte (“The Uncanny”136, énfasis mío).

Dentro de la poética piñeriana, el concepto freudiano de lo uncanny importa en tanto se emparenta con la imagen nueva que relata un fenómeno desconocido y aún familiar, pero posiblemente secreto y reprimido. La revelación de lo uncanny opera como una suerte de destrucción de ese mundo secreto a través de la insistencia en figuras que, en muchos casos, y como se ha apuntado, se corresponden con lo abyecto o lo inexplicable que reclama una interpretación. La revelación de este mundo añade a lo uncanny un contenido de certeza, en tanto que a la vez, dentro del terreno de la literatura, Freud le otorga a la ficción la posibilidad de mayor 
creación de figuras de este tipo, lo que en otras palabras puede entenderse como que, a mayor trabajo de la ficción dentro de las imágenes, mayor será la posibilidad de descubrir fenómenos que han sido considerados dentro del terreno social-real. En este sentido, el sistema piñeriano de la imagen de lo nuevo se vincula con lo uncanny. La extrañeza que la imagen nueva provoca contribuye al proceso cognitivo y devela lo reprimido por las normas, los tabúes y anquilosamiento social, y en esta relación muestra la construcción de una imagen-texto y texto-sujeto rebelde. El concepto de lo uncanny, que señala la posibilidad del nacimiento del sujeto a través de la imagen que lo descubre al penetrar y actuar dentro de lo desconocido, fortalece el concepto piñeriano sobre la escritura y guarda, al mismo tiempo, una profunda relación con el conocimiento del sujeto a través de la percepción de su otra imagen desconocida.

En estrecha relación con las ideas anteriores se encuentra también un ensayo como el de "Los dos cuerpos", en el que Virgilio, al igual que en "Contra y por la palabra", insiste en la necesidad de que el lenguaje sea una performance del sujeto que le facilite (re)conocerse. Sumamente teatral, como él mismo confesara, Virgilio propone el reconocimiento del sujeto a partir de la performance misma y la creación de ésta a partir de otra fricción, es decir, de otra mirada. En este ensayo, el dramaturgo insiste en mostrar la relación entre la mirada, la imagen, el teatro y el juego.$^{15}$ Virgilio recurre al teatro no sólo para proponerle un juego al ser humano, sino para avisar de la mirada o la visión que el ser humano tiene de las cosas. Mirada o visión cuyo origen se encuentra en el teatro, al explicar que el origen de esta palabra se halla en la raíz griega 'zeatron', que originalmente significaba mirar. En el acto de mirar al otro en la escena, el ser humano se perdía mucho más de lo que se encontraba. El efecto de mirar no siempre conllevaba el de ver, puesto que a veces la mirada más pertinaz de todas las cosas es la que menos ve (“Los dos cuerpos" 301).

El espacio teatral dentro de esta concepción tiene más de una función, y una de ellas es especialmente importante: este género y los efectos de su palabra son también sinónimos de magia, del uso del mito y de la remembranza de la memoria colectiva. La representación teatral cobra importancia dado que a través de ésta el espectador no sólo deberá descubrir las verdades de su propio cuerpo sino también las del cuerpo-teatro. La comparación entre el cuerpo-teatro con el cuerpo humano en su totalidad presenta, para Virgilio, la idea de que este arte es nosotros mismos, y tan sólo eso (301). La diferencia entre nuestro cuerpo de carne y hueso

15 Con marcada intención, Virgilio elige la palabra juego que tanto en inglés como en francés no sólo significa jugar sino también actuar. Para él, el acto de jugar potencia la imaginación y la libertad individual, idea que encuentra un antecedente y amplias resonancias en el pensamiento de la vanguardia romántica y, en especial, en el de Friedrich von Schiller (1759-1805). 
y nuestro cuerpo-teatro, de acuerdo con Virgilio, consiste en que el primero es sujeto pasivo y el segundo un cuerpo activo. Si lográramos que nuestra pasividad (la mirada que no ve) se insertara en su actividad (la imagen que se crea inscrita en el verbo), lo humano podría realizarse, según Piñera en el mismo ensayo, en tanto que personas sin máscaras (301). Es decir, en un juego donde lo humano se viera a partir de sí mismo, dentro de la representación, en su doblete ideal. Concepción casi posmodernista, diríamos, donde la autenticidad se juega en lo representado, dentro de la representación y fuera de lo estático.

La imagen aparece finalmente bajo el signo de la preocupación por los orígenes, erigida al revés ${ }^{16}$ en su contenido desconstructor (destructor) del imaginario nacional. Como he aludido antes, existe aún en Virgilio la comprensión modernista de que la poesía -representada en este sistema por medio de la imagen- es la piel del lenguaje y, por extensión, del individuo. En este punto, sin embargo, se lee extensivamente que la imagen o piel del lenguaje es también la piel de la sociedad de una manera diferente, inarmónica. Aparece en Virgilio Piñera una preocupación sobre el individuo y la nación en su posibilidad de performance o fricción con lo concreto. De este modo, mientras más concreta sea la fricción o performance del individuo dentro de su lenguaje diario, más éste utiliza la palabra, poesía o cultura como un instrumento para (re)conocerse y (re)construirse. La literatura significa así una construcción sobre lo concreto y lo real, una acción en contra del lenguaje fosilizado o su instrumentación establecida y envejecida dentro del terreno social. Toda acción del sujeto es, de este modo, un antidiscurso cultural frente a los discursos regulados y reguladores. La poética piñeriana es, en otras palabras, la posibilidad que el sujeto tiene de expresar su imaginación (pensamiento) y, por ende, si no logra realizarse como lo que es, al menos la posibilidad de performance le permite darse cuenta de sus múltiples máscaras sociales y su parálisis. La conciencia de esta fosilización, parece decir Virgilio, contribuye a que el sujeto comience a dar los primeros pasos para conocerse dentro de la alternancia identitaria de lo que es y lo que no es.

\footnotetext{
${ }^{16}$ Rasgo presente en toda la obra piñeriana y advertido por María Zambrano en 1948: "tiene su poesía mucho de confesión al revés [...] Poesía de alguien que es cuestión para sí mismo, sometido a la crítica, ante sí, en la raíz de su existencia” (“La Cuba secreta” 53, énfasis mío).
} 
Aguirre, Mirta. "La isla en peso. Un poema”. Gaceta del Caribe 1/3 (1944): 30.

Arrufat, Antón, ed. "Notas prologales". La isla en peso: obra poética. Madrid:

Tusquets Editores, 2000. 9-16. ed. Poesía y crítica. México: Cien del Mundo, 1994.

Baquero, Gastón. “Tendencias de nuestra literatura”. Anuario Cultural de Cuba (1944): 261-87.

Barthes, Roland. El placer del texto. Nicolás Rosa, trad. Buenos Aires: Siglo XXI, 1974.

Bianchi Ross, Ciro, ed. Imagen y posibilidad. La Habana: Editorial Letras Cubanas, 1981.

Calás, Nicolás. “Oración y poesía”. Poeta 2 (1943): s.n.

Carpentier, Alejo. “Un ascenso de medio siglo”. Ensayos. La Habana: Editorial Letras Cubanas, 1984. 273-303.

Diccionario de la Real Academia Española. Vigésima Segunda Edición. 2001.

Diego, Eliseo, ed. María Zambrano en Orígenes. México:Ediciones del Equilibrista, 1987.

Espinosa Domínguez, Carlos, ed. Virgilio Piñera en persona. Denver: Término Editorial, 2003.

ed. Teatro cubano contemporáneo. Madrid: FCE, 1992.

Freud, Sigmund. “The Uncanny”. Psychological Writings and Letters. Alix Strachey, trad. Sander L. Gilman, ed. Nueva York: Continuum, 1995. 120-53.

González Cruz, Iván, ed. José Lezama Lima: Fascinación de la memoria. La Habana: Editorial Letras Cubanas, 1994.

Inglis, David. ASociological History of Excretory Experience (Defecatory Manners and Toiletry Technologies). Lewiston: Edwin Mellen Press, 2001.

Kristeva, Julia. Sentido y sinsentido de la rebeldía. Guadalupe Santa Cruz, trad. Santiago: Editorial Cuarto Propio, 1999.

Lezama Lima, José. "Respuestas y nuevas interrogaciones. Carta abierta a Jorge Mañach”. Imagen y posibilidad. Ciro Bianchi Ross, ed. La Habana: Editorial Letras Cubanas, 1981. 184-90.

"Momento cubano de Juan Ramón Jiménez". Imagen y posibilidad. Ciro Bianchi Ross, ed. La Habana: Editorial Letras Cubanas, 1981. 66-71.

Parra, Nicanor. Poemas y antipoemas. Santiago: Nascimento, 1967.

Paz, Octavio. Los hijos del limo. Barcelona: Seix Barral, 1974.

Piñera, Virgilio. “Alfred Jarry, ‘joven airado’ de 1896”. Poesía y crítica. Antón Arrufat, ed. México: Cien del Mundo, 1994. 210-17. 
“Cartas de Virgilio”. José Lezama Lima: fascinación de la memoria. Iván González Cruz, ed. La Habana: Editorial Letras Cubanas, 1994. 261-84. "Cartas entre Jorge Mañach y Virgilio Piñera”. Virgilio Piñera en persona. Carlos Espinosa Domínguez, ed. Denver: Término Editorial, 2003. 88-91. “Contra y por la palabra”. Poesía y crítica. Antón Arrufat, ed. México: Cien del Mundo, 1994. 265-70.

Cuentos fríos. Buenos Aires: Editorial Losada, 1956.

"Gertrudis Gómez de Avellaneda: revisión de su poesía”. Poesía y crítica. Antón Arrufat, ed. México: Cien del Mundo, 1994. 145-69.

Electra Garrigó. Teatro cubano contemporáneo [1943]. Carlos Espinosa Domínguez, ed. Denver: Término Editorial, 2003. 140-86.

"El secreto de Kafka”. Poesía y crítica. Antón Arrufat, ed. México: Cien del Mundo, 1994. 230-34.

"El país del arte". Poesía y crítica. Antón Arrufat, ed. México: Cien del Mundo, 1994. 135-40.

“Freud y Freud”. Poesía y crítica. Antón Arrufat, ed. México: Cien del Mundo, 1994. 277-79.

La isla en peso: obra poética [1943]. Antón Arrufat, ed. México: Cien del Mundo, 1994.

"Los dos cuerpos”. Poesía y crítica. Antón Arrufat, ed. México: Cien del Mundo, 1994. 301-03.

Poeta. La Habana, 1942-1943. s.n.

“Poesía cubana del XIX”. Poesía y crítica. Antón Arrufat, ed. México: Cien del Mundo, 1994. 186-91.

Poesía y prosa. La Habana: Editorial Serafín García, 1944.

Portuondo, José Antonio. "El toro de Falaris. El poeta en su universo aprisionado”. Lyceum 11/12 (1938): 52-55.

Vitier, Cintio. "La aventura de Orígenes”. Fascinación de la memoria. Iván González Cruz, ed. La Habana: Editorial Letras Cubanas, 1994. 309-37.

"Virgilio Piñera: Poesía y prosa”. Orígenes 2/5 (abril, 1945): 47-50.

Wilcox, John C. Self and Image in Juan Ramón Jiménez. Chicago: U of Illinois P, 1987

Wittgenstein, Ludwig. Sobre la certeza. G.E.M. Anscombe y G.H. von Wright, eds.; Josep Lluís Prades y Vicente Raga, trads. Barcelona: Gedisa, 2000.

Zambrano, María. "Franz Kafka, mártir de la miseria humana”. Espuela de Plata 6 (agosto, 1941): 3-8.

"La Cuba secreta”. María Zambrano en Orígenes. Eliseo Diego, ed. México: Ediciones del Equilibrista, 1987. 43-56. 